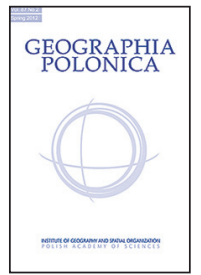

\title{
STRUCTURE OF THE FOREST ECOTONE IN THE BABIA GÓRA MASSIF, WESTERN CARPATHIANS
}

\section{Jerzy Szwagrzyk}

Institute of Forest Ecology and Silviculture

University of Agriculture in Krakow

Al. 29 listopada 46, 31-425 Krakow: Poland

e-mail: rlszwagr@cyf-kr.edu.pl

\begin{abstract}
The structure of forest stands and tree architecture at the forest ecotone were analysed at the Alpine timberline zone of the Babia Góra massif of the Western Carpathians. Tree stand and tree characteristics displayed large differences in various locations. On the north slope of the massif, trees at the timberline grow relatively tall and slender, and have narrow crowns. Trees at the timberline on the south-west facing slopes of the massif, at higher elevations, are shorter, with lower slenderness indices and relatively broader crowns. These results suggest, that different environmental factors play major roles in shaping the structure of the timberline in various elevations and various exposures.
\end{abstract}

\section{Key words}

Alpine timberline $\cdot$ subalpine spruce forests $\bullet$ tree architecture

\section{Introduction}

The upper limits of forest distribution in mountains share a special set of environmental conditions, producing characteristic forest structures. In high mountain areas, large changes, such as in temperature, snow cover depth, and wind speed occur in relatively short distances, affecting the vegetation in a very strong way (Körner 2012). Analysing the relations between environmental factors and plant growth and form, is easier than in other places. During the last two decades the Alpine timberlines throughout the world have attracted the attention of many scientists (Dullinger et al. 2004; Nagy 2006; Rai et al. 2012). There was an expectation, that the effects of global climate should be relatively strong and easy to document at the Alpine timberlines. Relatively small changes in climatic parameters could lead to significant changes in the structure of tree stands and in tree architecture in the Alpine timberlines (Smith et al. 2003).

In several studies, it has been documented that the elevation of the timberline in high mountains has already significantly increased 
over the last centuries or decades (Kullman 2002; Dullinger et al. 2004; Takahashi et al. 2012). However, in some cases the increase in the elevation of the timberline could be attributed to the changes in human management (especially the decline in sheep and cattle grazing in high-elevation meadows), than to climate changes (Guzik 2008; Lingua et al. 2008; Rai et al. 2012). In many mountain ranges throughout the world, the influence of grazing has been strong and persistent. For this reason, it is usually difficult to separate the effects of climate change from the effects of human management changes in the high mountain areas.

Tree stand structure at the forest ecotone could respond to climate changes faster than the elevation of the timberline (Smith et al. 2003; Nagy 2006; Zhang et al. 2009). The structural changes in plant community and the modifications of the tree architecture need less time than is necessary for the forest border to move a certain distance up the slope. Therefore, studying changes in tree size, crown architecture, and spatial patterns of trees could yield more information about the possible effects of global climate changes on forest ecotones. The structure of tree stands at the Alpine timberline has been already studied in various mountain ranges (Smith et al. 2003; Rai et al. 2012; Takahashi et al. 2012). Some of these papers were focused mainly on the spatial relationships among trees, trying to infer biological processes from spatial patterns (Lingua et al. 2008; Zhang et al. 2009). Other studies focused on analysing the size structure of trees (Rai et al. 2012) and tree architecture (Smith et al. 2003). It is well documented, that trees at the Alpine timberline grow shorter, and grow with asymmetric crowns (Awzan et al. 1987; Smith et al. 2003), and frequently they grow in groups or in lines (Myczkowski 1964; Lingua et al. 2008; Zhang et al. 2009). Such growth patterns are frequently the result of vegetative reproduction (Körner 2012) or regeneration of trees on the coarse woody debris -'nurse logs' (Holeksa 1998).

The structure of the Alpine timberline on Babia Góra Mt. has already been subjected to some detailed studies. These studies chiefly concern the north slope of the massif (Zientarski 1976; Awzan et al. 1987). There are still many unanswered questions, though, that have to do with the relationship between the tree architecture and the structure of tree stands on one hand, and the environmental factors affecting the timberline ecotone. Assuming that low temperatures of the growing season, sometimes coupled with a short growing season, are the most important factor/s shaping the Alpine timberline on a large scale (Körner 2012), the other factors, like winter winds, snow avalanches, and rockfalls, can strongly modify the timberline on the local scale. The effects of these factors are visible in tree forms. Thus, the analysis of tree architecture and stand pictures at the timberline can yield valuable insight into the functioning of tree populations of the high mountain ecotone.

\section{Study area}

The area of study was the massif of Babia Góra Mt. in the Western Carpathians, on the border between Poland and Slovakia. The elevation of Babia Góra's peak is 1725 m a.s.l. which is $300-400 \mathrm{~m}$ higher compared to the neighboring mountain ranges. The climate is cool and humid; at the timberline level of Babia Góra Mt. the mean annual temperature is about $2^{\circ} \mathrm{C}$, and the annual sum of precipitation is slightly over $1400 \mathrm{~mm}$ (Obrębska-Starkel 2004). The average duration of snow cover in the subalpine spruce forests in 156 days (Zientarski 1976; Łajczak 2004).

The vegetation of Babia Góra Mt. has been thoroughly studied by various groups of scientists (Celiński \& Wojterski 1978; Parusel et al. 2004). The subalpine spruce forests form a continuous belt around the Babia Góra massif. The dominant species is Norway spruce (Picea abies (L.) Karst.), and a small admixture is sometimes formed by rowan (Sorbus aucuparia L.) (Holeksa 2000). Despite the relatively uniform composition of the tree layer, the subalpine forests on Babia Góra Mt. are very diverse. That diversity is strongly reflected 
in the composition and structure of the forest floor vegetation. Four different units were identified by botanists within the association of the subalpine spruce forest PlagiothecioPiceetum (Kasprowicz 1996; Holeksa 2003; Parusel et al. 2004).

The lower border of the subalpine spruce forest belt is at an elevation of about 11001150 m a.s.l. (Bednarz et al. 2009). The timberline in the Babiogórski National Park (Polish part of the mountain) is located - according to Celiński and Wojterski (1978), and Bednarz et al. (2009) at elevations between 1350 and $1450 \mathrm{~m}$ a.s.l. on the north slope of the massif, and between 1400 and 1500 m a.s.l. on the south slope of the massif. In the Slovakian part of Babia Góra Mt., the timberline reaches an elevation of over 1500 m (Vorčak et al. 2006). Above the Alpine timberline there is a broad belt of shrubs, consisting mostly of dwarf mountain pine Pinus mugo, but in some places rowan Sorbus aucuparia are plentiful (Borysiak 1985; Żywiec \& Ledwoń 2008). Open places at the timberline and within the dwarf pine zone are usually characterised by lush vegetation, especially fern Athyrium distentifolium, tall herbs (Cicerbita alpina, Doronicum austriacum), and types of grasses (Calamagrostis villosa) (Kasprowicz 1996; Parusel et al. 2004).

\section{Methods}

This work was part of a bigger project, in which various factors associated with the timberline were studied: landforms, soils, climate, and radial increments of trees growing at the timberline.

Three sample plots for the analysis of the vegetation structure in the Alpine timberline ecotone were established on Babia Góra Mt. Two of the plots were on the south-western slopes of the mountain, in Slovakia. The third sample plot was on the north slope, in the middle part of the Babia Góra massif. Each sample plot was a circle with a $12.6 \mathrm{~m}$ radius. This means that the size of each plot was equal to $500 \mathrm{~m}^{2}$ in the vertical projection. In the plot, the exact location of each tree which had a DBH (diameter at the height of $1.3 \mathrm{~m}$ above the ground) that was thicker than $7 \mathrm{~cm}$ was determined by measuring the horizontal angle and the distance from the plot centre. Each tree's DBH was then measured, along with the tree height and the height of tree crown base. For each living tree, the crown radii were measured in the four cardinal directions. The status of each tree (alive, standing dead, broken) was determined. For standing dead trees, the $\mathrm{DBH}$ and tree height were measured, but no measurements of the crown were taken. For the broken or uprooted trees only the diameter of the trunk was measured.

In the middle part of each sample plot (a circle with a size of $100 \mathrm{~m}^{2}$ ) all smaller trees (taller than $50 \mathrm{~cm}$, but less than $7 \mathrm{~cm}$ in DBH), shrubs, dwarf shrubs, herbaceous plants, and mosses, were identified to species. The percent cover for each species was estimated visually.

On the basis of field measurements, the length of the tree crown (CL - difference between tree height and the height of the crown base) was calculated. Crown length divided by tree height and expressed as a percent was defined as the relative crown length $\left(\mathrm{CL}_{\text {rel }}\right)$. The slenderness of a tree was calculated as the tree height divided by tree $\mathrm{DBH}$, with both tree dimensions expressed in the same units. The sum of the crown radii in four cardinal directions divided by two was calculated as a crown width $(\mathrm{CW})$. The ration of crown length $(\mathrm{CL})$ to crown width $(\mathrm{CW})$ was employed as a measure of crown shape.

Statistical analyses included: calculating the basic statistical characteristics: mean value and standard deviation for each measured or calculated tree variable; determining the relationships between various tree variables using linear and non-linear methods, and testing the significance of differences between mean values using the Mann-Whitney U-test. The analyses were conducted using the STATISTICA 9.0 software package.

\section{Results}

The canopy cover of living trees varied between 23 and $48 \%$. In the sample plot, the 
number 2 tree stand was only composed of the spruce Picea abies, while in other sample plots there was a small admixture of rowan, Sorbus aucuparia, which made up from 2 to $10 \%$ of all tree stems. Tree density (calculated per one hectare) of living trees varied from $480 /$ ha to $580 /$ ha. Differences among the study plots were relatively small. Even more uniform were the densities calculated for only the live Norway spruce; from 480 to 520 stems per hectare (Tab. 1). The stand basal area of living trees was much more variable. In sample plot number one, the stand basal area amounted to $45 \mathrm{~m}^{2} / \mathrm{ha}$, which is a relatively high value for the forests growing in high elevations. On the other hand, in sample plot number 2, the basal area of live trees was only $16.5 \mathrm{~m}^{2} /$ ha (Tab. 1).

The cover of shrubs and young trees was low, ranging from 0 (plot 1) to 10\% (plot 2), while the cover of herbaceous vegetation and dwarf shrubs was much higher (70-90\%) (Tab. 2). The most common species in the field layer was the blueberry plant Vaccinium myrtillus. Other plants occurred in much lower abundances (Tab. 2). The total list of plant species was relatively short; apart from blueberry plants, the other relatively common plants were ferns: Athyrium distentifolium and Dryopteris dilatata, grasses - Calamagrostis villosa and Deschampsia flexuosa, and a low-stature herb Homogyne alpina. Other plants, like Vaccinium vitis-idaea, Luzula sylvatica, and raspberry Rubus idaeus, occurred only sporadically and had low cover values. Among the mosses, the most common species was Polytrichum formosum, while the other species; Plagiothecium undulatum, Dicranum scoparium, and Rhytidiadelphus squarrosus occurred in lower abundances (Tab. 2).

Tree diameter distributions also differed in the study plots. The thickest trees (up to $57 \mathrm{~cm}$ in $\mathrm{DBH}$ ) occurred in sample plot 1, while the thinnest ones (up to $32 \mathrm{~cm}$ in $\mathrm{DBH}$ ) - in sample plot 2. The differences in mean $\mathrm{DBH}$ were significant between plot 1 and plot $2(Z=3.63, p=0.0003)$, and between plot 2 and plot $3(Z=2.89, p=0.004)$. In plot 3, situated on the north slope of Babia Góra Mt. the spruce were definitely the tallest from among the analysed locations. The diameters of the spruce were smaller than in plot 1 , and the thickest tree attained slightly less than $50 \mathrm{~cm}$ in DBH (Fig. 1). However, there was no significant difference in the mean $\mathrm{DBH}$ between plot 1 and plot 3. In plot 2, the

Table 1. Characteristics of sample plots

\begin{tabular}{|l|c|c|c|}
\hline & plot 1 & plot 2 & plot 3 \\
\hline Elevation [m] & 1450 & 1500 & 1400 \\
Slope inclination [\%] & 15 & 10 & 30 \\
Aspect & W & SW & 580 \\
Number of live trees [ind./ha] & 480 & 520 & 500 \\
Number of live spruce [ind./ha] & 480 & 520 & 80 \\
Number of live rowan [ind./ha] & 0 & 0 & 20 \\
Number of dead rowan & 20 & & 140 \\
Number of dead standing trees [ind./ha] & 260 & 140 & 80 \\
Number of downed trees [ind./ha] & 20 & 140 & 35.5 \\
Basal area of live spruce [m2/ha] & 45 & 16.5 & 17 \\
Basal area of dead spruce [m2/ha] & 9 & 4.5 & 23 \\
Canopy cover [\%] & 48 & 24 & 5 \\
Shrub cover [\%] & 1 & 10 & 70 \\
Field layer cover [\%] & 80 & 90 & 20 \\
Moss cover [\%] & 35 & 10 & \\
\hline
\end{tabular}


trees had smaller diameters than in the other plots. Plot 2 was also more uniform in respect to tree sizes; the range and standard deviation of $\mathrm{DBH}$ values were definitely lower in plot 2 than in the other plots (Tab. 3).

Tree height was very diverse both within and between the sample plots. The tallest spruce were up to $17 \mathrm{~m}$ tall and occurred in the sample plot located on the north slope of the massif (plot 3), at an elevation of about $1400 \mathrm{~m}$ a.s.l. However, the shortest tree in that plot was only $3.6 \mathrm{~m}$ tall. On the south-west slopes of Babia Góra Mt. there was a very steep gradient in tree heights. Trees at the

Table 2. Vegetation of sample plots

\begin{tabular}{|c|c|c|c|}
\hline & & ver in [ & \\
\hline & Plot 1 & Plot 2 & Plot 3 \\
\hline Shrubs and tree saplings & & & \\
\hline Pinus mugo & & 10 & 2 \\
\hline Sorbus aucuparia & & & 1 \\
\hline Picea abies & & & 2 \\
\hline Juniperus nana & & 2 & \\
\hline Short shrubs and tree seedlin & & & \\
\hline Rubus idaeus & 3 & & \\
\hline Sorbus aucuparia & 1 & 1 & \\
\hline Picea abies & & & 1 \\
\hline Dwarf shrubs & & & \\
\hline Vaccinium myrtillus & 40 & 40 & 60 \\
\hline Vaccinium vitis-idaea & & & 2 \\
\hline Ferns & & & \\
\hline Athyrium distentifolium & 25 & 2 & \\
\hline Dryopteris dilatata & 5 & 2 & 5 \\
\hline Forbs & & & \\
\hline Homogyne alpina & 2 & 1 & 2 \\
\hline Rumex arifolius & 1 & & \\
\hline Grasses & & & \\
\hline Deschampsia flexuosa & 3 & 40 & 2 \\
\hline Calamagrostis villosa & 1 & 10 & \\
\hline Wood rushes & & & \\
\hline Luzula sylvatica & 1 & & \\
\hline Clubmosses & & & \\
\hline Huperzia selago & & & 1 \\
\hline Mosses & & & \\
\hline Polytrichum formosum & 20 & 10 & 15 \\
\hline Plagiothecium undulatum & 5 & & 5 \\
\hline Rhytidiadelphus squarrosus & 10 & & \\
\hline Dicranum scoparium & & & 3 \\
\hline
\end{tabular}


Table 3. Tree characteristics in sample plots

\begin{tabular}{|c|c|c|c|c|}
\hline & & plot 1 & plot 2 & plot 3 \\
\hline \multirow[t]{4}{*}{$\mathrm{DBH}$} & average & 31.5 & 20.2 & 28.4 \\
\hline & $\min$. & 7.3 & 7 & 9.6 \\
\hline & max. & 57.3 & 32.5 & 49.7 \\
\hline & STD & 13.54 & 6.68 & 11.21 \\
\hline \multirow[t]{4}{*}{ Height } & average & 9.9 & 7 & 10.2 \\
\hline & min. & 3.6 & 4.5 & 3.6 \\
\hline & $\max$. & 14.5 & 9 & 17 \\
\hline & STD & 2.95 & 1.42 & 3.61 \\
\hline \multirow[t]{4}{*}{ Slenderness } & average & 34.22 & 37.76 & 37.22 \\
\hline & $\min$. & 20.60 & 22.90 & 22.43 \\
\hline & $\max$. & 49.14 & 85.63 & 52.33 \\
\hline & STD & 9.06 & 13.74 & 8.19 \\
\hline \multirow[t]{4}{*}{ Relative Crown Length } & average & 76.7 & 76.38 & 72.74 \\
\hline & $\min$. & 41.7 & 53.3 & 46.67 \\
\hline & $\max$. & 100 & 92 & 95.45 \\
\hline & STD & 14.27 & 13.36 & 12.73 \\
\hline \multirow[t]{4}{*}{ Crown width (CW) } & average & 3.46 & 2.34 & 2.27 \\
\hline & $\min$. & 1.5 & 0.6 & 1.2 \\
\hline & $\max$. & 5.7 & 4.05 & 3.9 \\
\hline & STD & 1.26 & 0.81 & 0.71 \\
\hline \multirow[t]{4}{*}{$\mathrm{CL} / \mathrm{CW}$} & average & 2.26 & 2.55 & 3.28 \\
\hline & $\min$. & 1.38 & 1.04 & 1.67 \\
\hline & $\max$. & 3.33 & 5.83 & 5.09 \\
\hline & STD & 0.59 & 1.05 & 0,96 \\
\hline
\end{tabular}

elevation of $1450 \mathrm{~m}$ a.s.l. (sample plot 2) were up to $14.5 \mathrm{~m}$ tall, while in the uppermost location of the timberline (1500 $\mathrm{m}$ a.s.I.) the height of tallest trees attained barely $9.0 \mathrm{~m}$ (Tab. 3). The range of tree heights in plot 2 was definitely narrower than in the other locations, and the average tree height in plot 2 was significantly lower than in plot $3(Z=2.98, p \leq 0.0028)$ and in plot $1(Z=3.31, p=0.0008)$. The comparison of height-diameter curves produced for the three analysed plots (Fig. 2) showed, that the differences in tree heights increased with the tree $\mathrm{DBH}$. Among thinner trees, there was no substantial differences among the plots, but as trees grew thicker, there was an increasing difference in their heights.
The variability of the slenderness index among the analysed plots was very low. Values of the index which exceeded 50 were very rare; in fact, they were only found for relatively young and thin trees. The average values of the index of slenderness were between 34 (plot 1) and 38 (plot 2). None of the differences among the analysed plots were statistically significant. The minimum values were also very similar. In general, trees in plot 3 were consistently more slender than in plot 1 . There was one outlier among the trees growing in plot 2, which attained a slenderness index equal to 85 . This one finding made the results from that plot more variable than in other locations (Tab. 3). 
Tree crown lengths were proportional to tree height. In general, most of the trees had crown bases situated very close to ground level, although only in a small number of individuals did the lowest living branches actually touch the ground. Relative crown length showed little difference among sample plots; the average $\mathrm{RCL}$ ratio ranged from about $73 \%$ in plot 3 to $77 \%$ in plot 1 . None of the differences in relative crown length among the plots were statistically significant. Differences within plots were much larger than the differences between different elevations (Tab. 3). In general, all analysed spruce in the forest ecotone zone were characterised by long crowns.

Crown widths $(\mathrm{CW})$ displayed a different pattern; in this case, plot 1 was different from the other two. In plot 1 there were trees with average crown diameters of almost $3.5 \mathrm{~m}$, while in the two other plots, the mean crown diameters were more than $1 \mathrm{~m}$ smaller (Tab. 3). The differences between plot 1 and plot $2(Z=3.02, p=0.002)$ and plot 1 and plot $3(Z=3.34, p=0.0008)$ were statistically significant, while the differences between plot 3 and plot 2 were not. The range of crown widths and the standard deviation were also bigger in plot 1 compared with the two other plots. The relationship between crown width (CW) and tree DBH showed an opposite tendency to that of the relationship between tree height and tree $\mathrm{DBH}$. In plot 3, where the trees were tallest, the crowns were narrower than in the other plots. In the case of trees with large diameters, the difference in crown width between plot 3 and plot 2 was even two-fold (Fig. 3). Interestingly, there were also some differences between plots 1 and 2. Plot 2, situated at the highest elevation, was characterised by relatively broader crowns than the crowns in plot 1. Plot 1 was situated at a slightly lower elevation

Tree crown shape, expressed as a proportion of crown length $(\mathrm{CL})$ to crown width $(\mathrm{CW})$ differed a lot both among the sample plots and within them (Tab. 3). Plot 2 was the least consistent one, having the broadest range of $\mathrm{CL} / \mathrm{CW}$ values and a medium average (Tab. 3). The differences between plots 1 and 3 were easier to interpret. In the plot 1, located at the elevation of $1450 \mathrm{~m}$ a.s.l., crowns were relatively 'flat'. The average ratio of CL to CW was only 2.26, and the highest value was 3.33. This means that the range of crown shape indices was rather narrow. In plot 3, situated
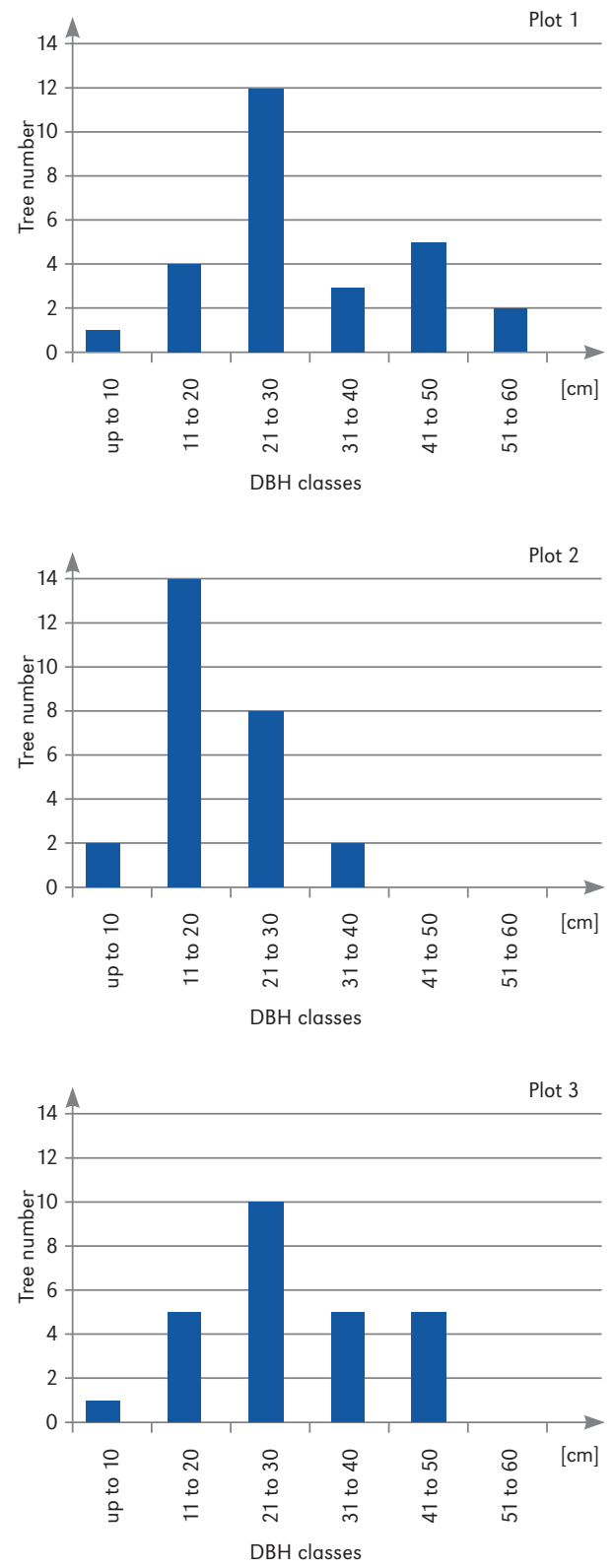

Figure 1. DBH distributions in the sample plots 


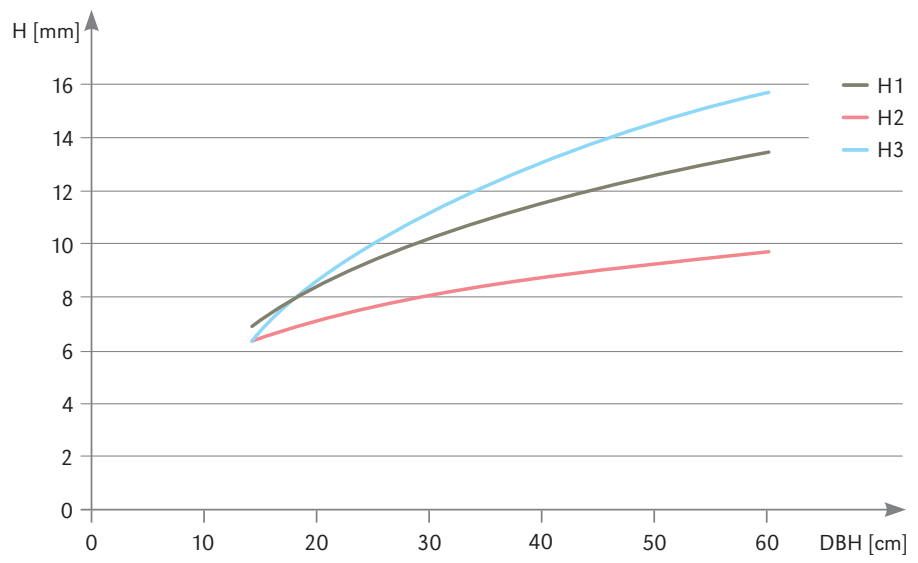

Figure 2. Height-DBH curves for three sample plots

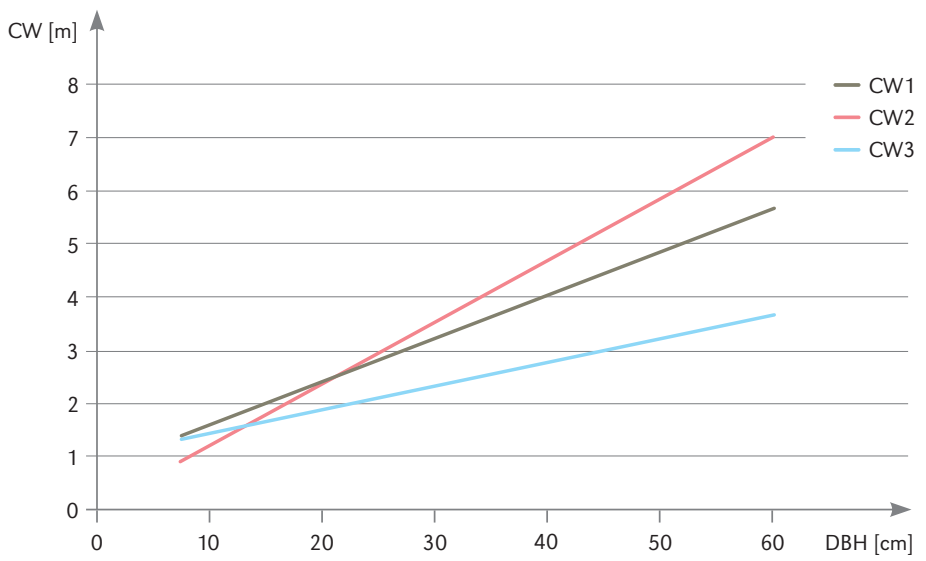

Figure 3. CW-DBH curves for plots 1, 2, and 3

at the elevation of $1400 \mathrm{~m}$ a.s.l., the average $\mathrm{CL} / \mathrm{CW}$ ratio was much higher (3.38), and so was the range of its variability. The highest value of $\mathrm{CL} / \mathrm{CW}$ ratio reached over 5 , while the lowest one was equal to 1.67 (Tab. 3).

\section{Discussion}

The cover of the tree crowns in the analysed ecotones of the Alpine timberline was much less than $50 \%$; only in one sample plot was it close to $50 \%$. It may seem a relatively low canopy cover. It is essential to consider, however, that visual estimations usually lead to an overestimation of the canopy coverage, so the values given in some papers might be overestimated. The size of the tree crowns in this study were measured, not estimated, so there was no chance for an overestimation of the canopy cover. In other timberline locations of Babia Góra Mt., the values of canopy cover lower than 50\% were also found by Awzan et al. (1987) almost 35 years earlier. In some approaches, the value of a canopy cover of $50 \%$ was considered as one of the criteria for defining the timberline (Sokołowski 1928). Apparently, even forest stands below the timberline ecotone may have a canopy 
cover lower than 50\% (Awzan et al. 1987; Jaworski \& Karczmarski 1995; Holeksa et al. 2004). Therefore, using the canopy cover criteria for defining the Alpine timberline could be rather misleading.

The timberline ecotone has often been considered a zone of intense competition between trees and shrubs - especially the Dwarf mountain pine Pinus mugo (Myczkowski 1964). In the analysed sample plots, the cover of shrubs in the timberline ecotone was very low (from 1 to 20\%). Very low values of shrub cover in the Alpine timberline ecotone in Babia Góra Mt. were also found by Awzan et al. (1987), and by Borysiak (1985). It seems that competition between spruce and shrubs like Rowan (Sorbus aucuparia), Dwarf mountain pine or Juniper (Juniperus nana), does not play an important role for the spruce growing at the timberline ecotones. Similar results have also been reported from other studies, where the results of spatial analyses suggested the prevalence of the facilitation effect - meaning that trees grow better when surrounded by shrubs (Lingua et al. 2008; Zhang et al. 2009). In harsh environments of the timberline ecotone, protection from wind can play a more important role than competition for light and other resources (Körner 2012).

The results of biometrical analyses showed significant differences in diameter and height distributions between the uppermost location of the timberline (1508 $\mathrm{m}$ a.s.l.) and lower localities. There were no significant differences between mean diameter and mean height in the south-west slope at an elevation of $1450 \mathrm{~m}$ a.s.l. and the north slope at an elevation of $1400 \mathrm{~m}$ a.s.l. The tallest trees (up to 17 meters in height) occurred on the north slope. These trees were also relatively slender, with rather narrow crowns. Much taller trees of up to $19.5 \mathrm{~m}$, were found by Zientarski (1976) in his study of the timberline on the north slope of Babia Góra Mt. at a slightly lower elevation (1380 m a.s.l.). On the other hand, in dense subalpine spruce forest-stands at the elevation of $1360 \mathrm{~m}$ a.s.I. (relatively close to the timberline) in the north slope of Babia Góra Mt., the height of the spruce attained at least 21 m (Jaworski \& Karczmarski 1995).

In the current study, the shortest (up to $9 \mathrm{~m}$ tall) and thickest trees were found in the south-west facing slope, where the timberline reaches its uppermost elevation in Babia Góra - 1508 m a.s.l. Spruce of similar heights had been recorded by Zientarski (1976) among the group of trees growing above the timberline of Babia Góra's north slope, at the elevation of $1400 \mathrm{~m}$ a.s.l. Awzan et al. (1987) also reported trees of similar stature growing above the timberline.

Trees at the timberline were relatively short and thick The height growth can be moderate in short trees, but it slows down once the trees grow high enough for their tops to be exposed to the wind (Körner 2012). Damage to tree tops was common. The breakage in the upper parts of the tree crowns can actually be lower, not higher. The index of slenderness in Norway spruce stands quite frequently attains values above 100 (Zientarski 1976; Jaworski \& Karczmarski 1995; Holeksa et al. 2008). At the timberline, the index of slenderness in Norway spruce stands was much lower, ranging on average, from 32 to 38 . The lowest values of the index of slenderness were found in plot 1, at an elevation of 1450 m a.s.l. However, if the slenderness was related to tree $\mathrm{DBH}$ (see Fig. 3), the trees at the uppermost location (plot 2 - elevation 1500 m a.s.l.) were definitely less slender than the trees in lot 1 . Plot 3 , located at an elevation of $1400 \mathrm{~m}$ a.s.l. on the north slope, definitely had the highest values of slenderness when related to diameter losses.

One of the interesting aspects of the functioning of the timberline ecotone is the relative importance of various groups of factors in different localities. The timberline on the north slope of Babia Góra Mt. is apparently shaped by forces associated with steep topography: avalanches, rockfall, and landslides. Trees growing in the timberline ecotone are relatively high, with narrow, rather regular crowns. The influence of wind on tree height and tree architecture is not obvious. Trees are not very thick wide, and the stand is relatively dense. 
These features suggest that the age of the spruce growing on the north slope is probably not very high. Similar situations like that of the trees growing at the timberline on the north slope of Babia Góra Mt. that are younger than trees growing in the tree stands at lower elevations - have already been described in the literature (Zientarski 1978; Bednarz et al. 2002) In the south-west slope, where the timberline reaches much higher elevations, forces associated with topography play a minor role. Climatic factors, especially wind, shape the tree architecture and restrict the height-growth of the spruce.

\section{References}

AwZAN L., Kasprowicz M., Węglarski K., 1987. Zmienność górnoreglowego boru karpackiego oraz morfologia świerka przy górnej granicy lasu na pótnocnych zboczach Babiej Góry. Rocznik Dendrologiczny, 37, pp. 5-24.

Bednarz Z., Holeksa J., Różański W., Szwagrzyk J., WILCZEK Z., ŻrWIEC M., 2009. Altitudinal ranges of forest and shrub communities in the Babia Góra Massif(West Carpathians) [in:] J. Holeksa, B. Babczyńska-Sendek, S. Wika (eds.), The role of geobotany in biodiversity conservation, Katowice: University of Silesia, pp. 71-80.

Bednarz Z., Jaroszewicz B., Ptak J., Szwagrzyk J. 2002. Dendrochronology of Norway spruce (Picea abies (L.) Karst.) in the Babia Góra National Park. Dendrochronologia, 16-17, pp. 45-55.

BORYSIAK J., 1985. Zespót jarzębiny Athyrio-Sorbetum ass. nova $w$ strefie górnej granicy lasu masywu Babiej Góry (Beskid Zachodni). Badania Fizjograficzne nad Polską Zachodniq. Seria B: Botanika, 36, pp. 115-132.

Celinski F., Wouterski T., 1978. Zespoły leśne masywu Babiej Góry. Warszawa-Poznań: Państwowe Wydawnictwo Naukowe.

Dullinger S., Dirnböck T., Grabherr G., 2004. Modelling climate change-driven timberline shifts: Relative effects of temperature increase, dispersal and invasibility. Journal of Ecology, vol. 92, no. 2, pp. 241-252.

Guzık M., 2008. Analiza wpływu czynników naturalnych i antropogenicznych na kształtowanie się

\section{Acknowledgements}

This work was part of the research project entitled, Natural and anthropogenic conditioning of the occurrence of the upper timberline on Babia Góra Mountain, and its dynamics over the last 200 years, and was supported by a research project MNiSW N N306 070640.

\section{Editors' note:}

Unless otherwise stated, the sources of tables and figures are the authors' on the basis of their own research.

zasięgu lasu i kosodrzewiny w Tatrach. Kraków: Uniwersytet Rolniczy [Unpublished PhD thesis].

HolekSA J., 1998. Rozpad drzewostanu i odnowienie świerka a struktura i dynamika karpackiego boru górnoreglowego. Monographiae Botanice, 82, Łódź: Polskie Towarzystwo Botaniczne.

HolekSA J., 2000. Distribution of Sorbus aucuparia (Rosaceae) regeneration in relation to trees in a subalpine spruce forest (W Carpathians, Poland). Fragmenta Floristica et Geobotanica, vol. 45, no. 1-2, pp. 203-212.

HoleksA J., 2003. Relationship between field-layer vegetation and canopy openings in a Carpathian subalpine spruce forest. Plant Ecology, vol. 168, no. 1, pp. 57-67.

Holeksa J., SzWagrzyk J., Musiałowicz W., ParuSEL J. B., 2004. Struktura i dynamika lasów Babiogórskiego Parku Narodowego [in:] B.W. Wołoszyn, A. Jaworski, J. Szwagrzyk (eds.), Babiogórski Park Narodowy. Monografia przyrodnicza, Kraków: Wydawnictwo i Drukarnia Towarzystwa Słowaków w Polsce, pp. 527-600.

Holeksa J., Żrwiec M., Parusel J., Szewczyk J., ZielonKA T., 2008. Subalpine spruce forests in the Babia Góra National Park [in:] M. Saniga, S. Kucbel, J. Holeksa, M. Żywiec, J. Parusel, J. Szewczyk, T. Zielonka, A. Jaworski, Z. Kołodziej, L. Bartkowicz (eds.), Structure, production, coarse woody debris and regeneration processes of Norway spruce natural forest in National Nature Reserves Babia hora and Pilsko, Zvolen: Technical University, pp. 49-96. 
JAWORSKI A., KarCZMARSKI J., 1995. Budowa, struktura, dynamika i możliwości produkcyjne górnoreglowych borów świerkowych w Babiogórskim Parku Narodowym. Acta Agraria et Silvestria. Series Silvestris, 33, pp. 75-113.

KASPROWICZ M., 1996. Zróżnicowanie i przekształcenia roślinności pięter reglowych masywu Babiej Góry (Karpaty Zachodnie). Idee Ekologiczne, 9, Poznań: Sorus, pp. 1-215.

KÖRNER C., 2012. Alpine treelines: Functional ecology of the global high elevation tree limits. Basel-Heidelberg-New York: Springer.

KULLMAN L., 2002. Rapid recent range-marin rise of tree and shrub species in the Swedish Scandes. Journal of Ecology, vol. 90, no. 1, pp. 68-76.

Lingua E., Cherubini P., Motta R., Nola P., 2008. Spatial structure along an altitudinal gradient in the Italian central Alps suggests competition and facilitation among coniferous species. Journal of Vegetation Science, vol. 19, no. 3, pp. 425-436.

Łauczak A., 2004. Pokrywa śnieżna Babiej Góry [in:] B.W. Wołoszyn, A. Jaworski, J. Szwagrzyk (eds.), Babiogórski Park Narodowy. Monografia przyrodnicza, Kraków: Wydawnictwo i Drukarnia Towarzystwa Słowaków w Polsce, pp. 153-178.

MrCZKOWSKI S., 1964. Struktura i ekologia zespołu świerka Piceetum tatricum u górnej granicy zasięgu w Tatrzańskim Parku Narodowym w okolicach Stawów Gqusienicowych i Pańszczycy. Ochrona Przyrody, 30, pp. 51-105.

NAGY L., 2006. European high mountain (Alpine) vegetation and its suitability for indicating climate change impacts. Biology \& Environment: Proceedings of the Royal Irish Academy, vol. 106, no. 3, pp. 335-341.

Obrebska-Starkel B., 2004. Klimat masywu Babiej Góry. [in:] B.W. Wołoszyn, A. Jaworski, J. Szwagrzyk (eds.), Babiogórski Park Narodowy. Monografia przyrodnicza, Kraków: Wydawnictwo i Drukarnia Towarzystwa Słowaków w Polsce, pp. 137-152.
Parusel J., Kasprowicz M,. Holeksa J., 2004. Zbiorowiska leśne i zaroślowe BgPN [in:] B. W. Wołoszyn, A. Jaworski, J. Szwagrzyk (eds.), Babiogórski Park Narodowy. Monografia przyrodnicza, Kraków: Wydawnictwo i Drukarnia Towarzystwa Słowaków w Polsce, pp. 429-476.

Rai I.D., Adhikari B.S., Rawat G.S., Bargali K., 2012. Community structure along timberline ecotone in relation to micro-topography and disturbance in Western Himalaya. Notulae Scientia Biologicae, vol. 4, no. 2, pp. 41-52.

Smith W. K., Germino M.J., Hancock T.E., JohnSON D.M., 2003. Another perspective on altitudinal limits of alpine timberlines. Tree Physiology, vol. 23, no. 16, pp. 1101-1112.

SOKOŁOWSKI M., 1928. O górnej granicy lasu w Tatrach. Zakład Badania Drzew i Lasu, 1, Kraków: Wydawnictwo Fundacji Zakłady Kórnickie.

TAKaHASHI K., HiRosawa T., Morishima R., 2012. How the timberline formed: Altitudinal changes in stand structure and dynamics around the timberline in central Japan. Annals of Botany, vol. 109, no. 6, pp. 1165-1174.

VorČÁK J., Merganič J., SANIGA M., 2006. Structural diversity change and regeneration processes of the Norway spruce natural forest in Babia hora NNR in relation to altitude. Journal of Forest Science, vol. 52, no. 9, pp. 399-409.

Zhang Q., Zhang Y., Peng S., Yirdaw E., Wu N., 2009. Spatial structure of Alpine trees in Mountain Baima Xueshan on the Southeast Tibetan Plateau. Silva Fennica, vol. 43, no. 2, pp. 197-208.

ZientARSKI J., 1976. Wpływ wzniesienia nad poziomem morza na zagęszczenie i ukształtowanie górnoreglowych borów świerkowych w Babiogórskim Parku Narodowym. Prace Komisji Nauk Rolniczych i Komisji Nauk Leśnych, 42, Poznań: Poznańskie Towarzystwo Przyjaciół Nauk, pp. 137-149.

ŻrwieC M., Ledwoń M., 2008. Spatial and temporal patterns of rowan (Sorbus aucuparia L.) regeneration in subalpine spruce forest in West Carpathians. Plant Ecology, vol. 194, no. 2, pp. 283-291. 
http://rcin.org.pl 